\title{
The Efficiency of Islamic Banks and Conventional Banks in Indonesia Using Data Envelopment Analysis Approach
}

\author{
Retno Fitrianti ${ }^{1}$, Sri Undai Nurbayani ${ }^{2}$ \\ \{retno_fitrianti@fe.unhas.ac.id ${ }^{1}$, sri.undai@gmail.com ${ }^{2}$ \} \\ Faculty of Economics and Business, Hasanuddin University, Makassar, Indonesia. ${ }^{1,2}$
}

\begin{abstract}
Banking sector mediation is related to efficiency in economic performance. As a financial institution, banks need to maintain their performance in order to operate optimally, one factor that must be considered is efficiency in performance. This research aimed to analyze the efficiency of Islamic Banks and Conventional Commercial Bank in Indonesia. Using a purposive sample technique for two Islamic banks and two commercial banks. Fixed assets, deposits, and other operating expenses as input variables used, while credit as output variable. Using Data Envelopment Analysis to calculate the efficiency of banking. The results show that all Sharia Commercial Bank samples reached efficiency level 1 was efficient. Besides, the sample of conventional commercial banks used in this study is not all efficient. This is due to one of the sample banks having an efficiency level below one, which is 0.644 . It means that conventional bank groups are inefficient.
\end{abstract}

Keywords:

Efficiency, Islmic Banks, Conventional Banks, DEA

JEL Classification: G21, G28

Article Received: 18 October 2020, Revised: 3 November 2020, Accepted: 24 December 2020

\section{Introduction}

The development of Islamic banking in Indonesia has become a benchmark for the success of Islamic economic existence. Bank Muamalat as the first Islamic bank and became a pioneer for other Islamic banks has first implemented this system in the midst of the mushrooming of conventional banks. The Financial Services Authority (OJK) states that the development of Islamic banking in the past 8 years is classified as rapid. The concept of efficiency in banking is one of the parameters of performance that is quite popular, because it is widely used to answer the difficulties in calculating performance measures as mentioned above. The identification of input and output allocations is further analyzed to see the causes of inefficiency.

Along with the development of Islamic banking, Islamic banking finance expansion quantity also rose significantly. Islamic banking development according to the FSA at least can be monitored with indicators such as total ThirdParty Fund (DPK), total assets, and total financing disbursed. However, this amount is still far below the indicators achieved by conventional banking. Islamic banking also only gets a market share of around $4 \%$. Table 1 report a comparison table of indicators of Islamic Bank and Commercial Bank following:

Table 1. Component Indicators Conventional and Islamic Banks period 2014-2016 (Billion Rupiah)

\begin{tabular}{cccccccc}
\hline \multicolumn{4}{c}{ Conventional } & \multicolumn{4}{c}{ Islamic } \\
\hline Years & Asset & DPK & Crdit & Years & Asset & DPK & Credit \\
2014 & 5.410 .098 & 4.114 .420 & 3.706 .501 & 2014 & 204.961 & 170.723 & $\mathbf{1 4 7 . 9 4 4}$ \\
2015 & 5.919 .390 & 4.413 .056 & 4.092 .104 & 2015 & 213.423 & 174.895 & $\mathbf{1 5 3 . 9 6 8}$ \\
2016 & 6.475 .602 & 4.092 .104 & 4.413 .414 & 2016 & 254.184 & 206.407 & $\mathbf{1 7 7 . 4 8 2}$ \\
\hline
\end{tabular}

Source: Indonesian Banking Statistics, OJK, 2016, own processed. 
In the Islamic banks and conventional banks are good assets, deposits and financing increased. Sharia banking assets as a whole at the end of 2016 were at the level of 254.184 billion rupiah. Although there is a significant increase every year, the assets of Islamic commercial banks are still very low when compared to conventional commercial bank assets which penetrated $6,475,602$ billion in 2016, as well as other financial indicators.

As a financial institution, banks need to maintain their performance in order to operate optimally. Moreover, Islamic banks must compete with the dominant and rapidly developing conventional banks in Indonesia. Increasingly intense competition must be coupled with good management to survive in the industry. One factor that must be considered by banks to be able to survive is the efficiency in performance. According Muharam and Pusvitasari (2007) that banking efficiency is almost equal to the company, the efficiency of the banking user define a benchmark for measuring the performance bank where efficiency is a response to the difficulty in calculating measures of performance such as the level of efficiency in the allocation, technical and total efficiency. Efficiency measurement by three approaches, are Using Rasio, Regression and Frontier Aproachs

Generally, there are many efficiency studies using DEA (Data Envelope Analysis) method. The empirical results also support the findings of a number of studies in various countries. Rosman, et al (2014), Ahmad A (2010), Onur and Abdalla (2010), Hadad et al (2008), Hamin et al (2008), Sulfan et al (2008). Studies on bank efficiency have been carried out on Islamic banks and conventional banks using Data Envelopment Analysis (DEA) methods. Akhmad Syakir Kurnia (2004) is measuring the intermediation efficiency of the 11 largest banks in Indonesia by using the Data Envelopment Analysis (DEA) method. Using saving, operational cost, credit, current asset and operating income variablels. The results of this study states that all government banks experiencing inefficiency in the period of 2002. In the period 2003 Bank Mandiri only achieve efficiencies. Foreign banks are represented Citibank shows the efficiency at the boundaries of frontier during the period 2002 and 2003. Moreover, it can be concluded that the major banks are not more efficient than smaller banks. Larger banks in terms of assets, collection and distribution of funds does not mean efficient in carrying out the intermediation function.

Fadzlan Sufian (2007) which measures the relative efficiency between foreign Islamic banks and domestic Islamic bank in Malaysia by using Data Envelopment Analysis (DEA). The results of this study found that Malaysian Islamic banking experienced a decrease in the level of efficiency in the 2002 period and returned to a little better in the 2003 and 2004 periods, domestic Islamic banks had a slightly higher level of efficiency compared to foreign Islamic banks. Research by Shamsher Mohamad, Taufiq Hassan, Mohamed KhaledI, Badar (2008) entitled "Efficiency of Conventional versus Islamic Banks: International Evidence using Data Envelopment Analysis". This study uses an intermediation approach. The input variables used are Labor, Fixed Asset, Total Funds, while the output variables used are Total Loans, Other Earning Asset, Off-Balance Sheet Items. The results of this study indicate there is no significant difference between the efficiency of Conventional Banks and Sharia Banks in 21 Countries that are the object of research.

Salwa F and Saad N (2010) found that The overall results show that scale efficiency dominates the effect of pure technical efficiency in determining the overall or technical efficiency of Malaysian Islamic banks. Another important finding obtained from this study is that the performance of Malaysian-owned Islamic banks is better compared to their foreign-owned counterparts. The findings of this study are important for Islamic banks in Malaysia to improve or maintain the ability to be more competitive and provide better and better alternatives to conventional banking systems. Ahmad and Abdul-Rahman (2012) examined the relative efficiency of Islamic commercial banks 
and conventional commercial banks in Malaysia using DEA for the period 2003 to 2007. They found that conventional commercial banks outperformed Islamic commercial banks in terms of reduction and showed Islamic inefficient than commercial banks because of managerial efficiency and technological progress. Rosman, et all (2014) examines the efficiency level ofIslamic banks during the financial crisis specifically in Middle Easternand Asian countries from 2007 to 2010. The findings explain that Islamic banks were able to sustain operations through the crisis. However, the study also shows that the majority of these Islamic banks were scale inefficient. Most of the scale inefficient banks were operating at decreasing returns to scale. This study also found that both profitability and capitalization were the main determinants of Islamic banking efficiency

Wilson Arafat (2006) stated that the problem of banking efficiency to be especially important today and in the future, because, among other things: (1) competition increasing competition; (2) Problems that arise as a result of reduced resources; (3) improve customer satisfaction standards. Therefore, an analysis of banking efficiency in Indonesia is urgently needed to find out and determine the causes of changes in efficiency and subsequently take corrective action so that improvements in efficiency can be carried out as they should.

The purpose of this study was to analyze the efficiency of Islamic Banks and Commercial Bank in Indonesia 2016 period.

\section{Research Methodology}

DEA is one of the non-parametric analysis tools used to measure efficiency relatively well between profit-oriented business organizations as well as between non-profit oriented organizations or economic activity actors in the production process or activities involving the use of certain inputs to produce certain outputs was wasfirst introduced in a model developed by Charnes et al. (1978). This analysis can also measure the efficiency of bases and policy makers in improving efficiency.
In the calculation there are 2 models used in measuring the efficiency of an Economic Activity Unit (UKE), namely, the CCR model or better known as Constant Return to Scale (CRS) and the BCC model (Banker, Charnes, Cooper) or better known as Variable Return to Scale (VRS). The CRS approach is more appropriate when the bank can operate at an optimal scale (optimal scale) but considering that a bank is very difficult to operate optimally due to external conditions, the approach used is VRS.

This study employed Data Envelopement analysis (DEA). DEA approach to purpose evaluate the Economic Work Unit (UKE). Efficiency of Economic Work Units through the BCC model (Banker, Charnes, Cooper) with the assumption of Return to Scale.

The formula of variable returns to scale can be written as follows:

$$
\sum_{j=1}^{n} x j=1
$$

Furthermore, the BBC model can be written with the following equation;

Max $\theta$ (Effuciency of DMU model VRS)

$$
\begin{gathered}
\Sigma_{\mathrm{j}}^{\mathrm{n}}=1^{\prime} i j \geq x i 0 \\
\mathrm{i}=1,2, \ldots, \mathrm{m} \\
\Sigma_{\mathrm{j}}^{\mathrm{n}}=1^{\prime} j \geq y i 0 \\
\mathrm{r}=1,2, \ldots, \mathrm{j} \\
\Sigma_{\mathrm{j}}^{\mathrm{n}}=1 ' j \geq 1 \\
(\mathrm{VRS}) \\
\Sigma_{\mathrm{j}}^{\mathrm{n}}=1 ' \mathrm{\prime} \geq 0 \\
\mathrm{j}=1,2, \ldots, \mathrm{n}
\end{gathered}
$$

The value of the efficiency is less or equal to 1 . The Economic Activity Unit (UKE) whose efficiency value is less than 1 means inefficiency while the Economic Activity Unit (UKE) whose value is equal to 1 means the Economic Activity Unit (UKE) is efficient.

3 Result and Discussion 
Summary of relationship between input and output variable is shown in table 2. Table two shown group of Islamic Bank are Syariah Mega Indonesia (SMI) and Panin Dubai Syariah (PDS); and group of Mega Bank (MB) and Panin Indonesia Bank (PIB). The input variable consist of Fixed Asset, Saving and Opperational Cost, but Output variable is Credit.

Table 2. Input and Output Variables

(Study of 2 Islamic Banks and 2 Conventional Banks, periode 2016, million rupiahs)

\begin{tabular}{llrlrr}
\hline No & Banks & $\begin{array}{c}\text { Opertional } \\
\text { Cost }\end{array}$ & Fixed Asset & Saving & \multicolumn{1}{c}{ Output } \\
Credit
\end{tabular}

Sources: - Otoritas Jasa Keuangan, Banking Financial Report, 2016

- Own Work

The table shows that the fixed assets of Islamic Bank is low if compare with fixed assets of Commercial Bank. The inequality may illustrate that the condition of banks in Indonesia is still dominated by conventional banks. Similarly, the largest savings data are dominated by conventional banks. Other operational costs are direct costs related to bank operations. The data used in this study are labor costs and other costs attached to the bank's income statement and comprehensive income. The reason for using this variable is because other operational costs are used as a measure of costs incurred by banks in their operational activities as institutions that deposit and distribute funds to the public or intermediary institutions. According the table 2, Operational costs Islamic bank are less than Conventional bank. output variables used are loans which are the product of banking fund distribution to the public, both individuals and legal entities for investment, trade or consumption, which can provide benefits for the bank with the interest or for the results. The selection of this variable as output is because the bank's main product as an intermediary is credit

The results of the calculation of the DEA model are orientated output with the assumption of Variable Return to Scale (VRS) using the DEAP 2.1 application, it can be seen the efficiency levels of 2 Islamic Banks and 2 Conventional Banks in Indonesia in table 2 These results can illustrate the achievement of the value of efficiency at each bank. Based on the results of these calculations in table 4.7 shows that Bank Mega Syariah achieved an efficiency level of 1 in the 2016 period, Bank Panin Dubai Syariah also achieved an efficiency level of 1 in the same period. Bank Mega achieved an efficiency level of 0.644 in the 2016 period and Bank Panin achieved an efficiency level of 1 in the same period.

Tabel 3. Efficiency Value Islamic Banks and Conventional Banks Period 2016

\begin{tabular}{lcc}
\hline No. & Banks & Efficiency Value \\
\hline \multicolumn{2}{l}{ Islamic Banks } & \\
\hline 1 & Mega Syariah & 1.00 \\
2 & Panin Dubai Syariah & 1.00 \\
\hline
\end{tabular}




\begin{tabular}{crr}
\hline 1 & Panin Bank & 0.64 \\
2 & Mega Bank & 1.00 \\
\hline
\end{tabular}

Sources: Own Work ((DEAP 2.1 Output-Orientated, VRS)

Based on the findings that have been reported on the results of research statistics that show the bank that the sample in this study, including three banks, namely Bank Mega Syariah, Dubai Islamic Bank and Bank Panin Panin achieve efficiency levels 1 and expected efficiency. These banks have approved the input or output value of the previously used (produced) in the production operation can be operated relatively efficiently. While the bank is experiencing inefficiency of Bank Mega, which only reached an efficiency of 0.644. If each bank are grouped according to the principle works, it can be concluded that the Islamic Banks performance better than that of conventional commercial bank in terms of efficiency. This finding is support by Syakir (2004), Purwanto (2011), Kustanti and Indriani (2016), which states that Islamic Banks are more efficient than Conventional Banks in Indonesia. Similarly, study of Pradiknas and Faturohman (2015) find that Islamic banks are more efficient than conventional banks in Indonesia.

Banks are experiencing inefficiencies, according to findings in a table of values Original Value, Projected Value, Radial Movement and Movement Slack turns the input variable deposits, other operating expenses and credits that led to inefficiencies at Bank Mega. On the input there is an excess deposit amounting to 220,684.087 million of the amounts of deposits that should be collected from the community. The condition of savings that exceeds the efficiency target will greatly affect capital development. Inefficient storage of input occurs because of its use which is less productive and not optimal.

Other operational costs that exceeded the efficiency target of 1,489,941,706 million rupiah which caused inefficiency at Mega Bank. The swelling costs were one of them due to an increase in non-performing loans (NPL) in 2016 by $0.63 \%$ from 2015 with an NPL of 2.81\% (Bank Mega annual report data in 2016). In accordance with the study of Sri Hermuningsih and Dewi Kusuma Wardani (2013) which states that high NPLs cause high bank operational costs that have the potential to reduce profits. Inaccuracy in analyzing the debtor as well as providing excess credit amount and overreach often a factor that led to the high risk of bad debts. Increased supervision and implementation of prudential banking principles as a whole can be a solution for banks in reducing the amount of bad loans or NPLs

Increasing labor costs that are not supported by productivity will also lead to inefficiencies in banks. This can be seen in Bank Mega's annual consolidated financial statements, where the increase in labor costs from 1,109,425 million rupiah in 2015 to $1,137,784$ million rupiah in 2016 but interest income decreased by 306,362 million rupiah from the 2015 period of $6,458,281$ million rupiah to $6,151,919$ million rupiah in the 2016 period. Operating income, besides interest, also decreased by 4.331 million rupiah from the 2015 period of $1,949,305$ to $1,944.974$ million rupiah. Therefore, minimizing the workforce and maximize the functions of the task will be a solution to overcome these problems.

Inefficiency also occurred in the credit output variables Bank Mega. The differences in the projected value of Original Value and Value of Bank Mega not optimal in period of 2016 signifies the Bank's performance to public funds. Fixed assets amounted to 70,531,682, the bank should have been able to extend credit to the public amounted to $43,927,414.171$ million rupiahs. Lending can affect the development of capital because the results of bank lending obtain a fairly high interest income. So this can increase profits and lead to capital development. Increased profits and capital development can maintain the existence of banks in the swift competition in the banking industry. One alternative that can be taken by mega banks in maximizing output is by lowering interest rates. It can encourage people to 
choose the mega banks as creditors because they are not burdened with high interest rates.

As an intermediary institution, banks should have efficiency in their operational activities. In addition to maintaining its existence in the banking industry, banking efficiency will greatly affect the economy of a country, including the Indonesian state. This is in accordance with a number of studies that found that Indonesia Islamic banks are more efficient compared to conventional banks.

\section{Conclusion}

Four units of banks in our samples (2 Islamic banks and conventional banks 2), there are three banks that achieve efficiency levels of 1 , which means the bank is efficient in its operations in the period in 2016. Each of the Islamic Banks (Bank Mega Syariah and Dubai Islamic Bank Panin) achieve efficiency levels of 1 or otherwise efficient. Conventional two-Bank of the study sample, only one bank that achieve efficiency levels of 1 or otherwise efficient that Panin Bank, while Bank Mega achieve efficiency levels of 0644 and means inefficient. Inefficiency of Bank Mega originates from Savings input, Other Operating Expenses, and Credit Output in the period 2016. The inefficient input of savings occurs because of its use is less than the maximum, there is a waste of use of other operational expense inputs. Credit as Output experiences inefficiency because its original value is still lower than the projected Value that should be achieved.

\section{References}

[1] Ahmad A, Rehman K, and Saif MI. (2010). Islamic Banking Experience of Pakistan: Camparison between Islamic and conventional Banks

[2] Arafat, Wilson. 2006. Manajemen perbankan Indonesia, Jakarta: LP3ES

[3] Charnes, A., Cooper, W.W and Rhodes, E. (1978) Measuring the efficiency of DMUs,
European Journal of Operational Research, 2, p. 429-444.

[4] Hadad M, Hall M, Kenjegalieva K, Santodo W, Satruia R, and Simper R. (2008), Efficiency Indonesian Banking : Recent Evidence, Discussion Paper Series WP 2008-13, Departement Economics, Loughborough Universiti, ISSN: 1750 4171

[5] Hamim S, Mokhtar A, Abdullah N, Alhabshi S. (2008), Efficiency and Competition of Islamic Banking in Malaysia, Humanomics, 24 (1): 28-48

[6] Hermuningsi, Sri dan Dewi KusumaWardani. 2013. Faktor-Faktor Yang Mempengaruhi Kinerja Bank Dengan Skim Bunga Kredit Sebagai Varabel Intervening. Proceeding Call For Papers dan Seminar Nasional Fakultas Ekonomi UNS. Jawa Tengah.

[7] Kurnia, Akhmad Syakir 2004, "Mengukur Efisiensi Intermediasi Sebelas Bank Terbesar Indonesia Dengan Pendekatan Data Envelopment Analysis (DEA)," Jurnal Bisnis Strategi Vol. 13, Hal. 126139, Semarang.

[8] Kustanti, H and Indriani, A (2016). Analisis Perbandingan Efisiensi Bank Umum Syariah (BUS) dan Unit Usaha Syariah (UUS) dengan metode Stochastic Frontier Analysis (SFA) Periode 2010 2014. Diponegoro Journal Of Management, 5(3): 1-10.

[9] Muhamad, Shamsher, et al. (2008). "Efficiency of Conventional versus Islamic Banks: International Evidence using the Data Envelopment Analysis (DEA)". Journal of Islamic Economics, Banking and Finance, Hal. 23-65.

[10] Muharam, H dan Rizki Pusvitasari. 2007. "Analisis Perbandingan Efisiensi Bank Syariah dengan Metode Data Envelopment Analysis (Periode tahun 2005)". Jurnal Ekonomi dan Bisnis Islam, Vol.2 No.3

[11] Onour I and Abdalla A. (2010), Scale and Technical Efficiency of Islamic Bank in 
Sudan: Data Envelopment Analysis, MPRA Papper No. 29885.

[12] T.Y. Pradiknas, T. Faturohman (2015) Efficiency of Islamic Banking Compared to the Conventional Banking: Evidence from Indonesian Banking Sector, Journal of Business and Management, 4 (5), pp. 540-551

[13] Rosman R, Wahab N, and Zainol Z. (2014), Efficiency of Islamic Banks During the Financial Crisis: an Analysis of Middle Eastern and asian Countries, Pacific-Basin Finance Journal 28 : 76 - 90

[14] Salwa, F and Saad, N. (2010), An Analysis on the Efficiency of Malaysian Islamic Banking Industry : Domestic vs. Foreign, Review of Islamic Economics 14 (1): 2747

[15] Shamsher Mohamad, Taufiq Hassan, Mohamed Khaled, Badar. (2008). Efficiency of Conventional versus Islamic Banks: International Evidence using the Stochastic Frontier Approach (SFA). Journal of Islamic Economics, Banking and Finance.

[16] Sufian F, Mohammad N, Zulkhibri M, Majid A. (2008), The efficiency of Islamic Banks: Empirical Evidence from the MENA and Asian Countries Islamic Banking Sectors, MPRA Paper No. 19072. 